\begin{tabular}{|c|c|c|}
\hline()$_{\text {Siirt }}$ & $\begin{array}{c}\text { Türkiye Tarımsal Araştırmalar Dergisi } \\
\text { dergipark.org.tr/tutad }\end{array}$ & $\begin{array}{l}\text { Turk J Agric Res } \\
\text { 2021, 8(3): 261-272 } \\
\text { ○ TÜTAD } \\
\text { ISSN: 2148-2306 }\end{array}$ \\
\hline 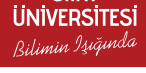 & Araştırma Makalesi / Research Article & $\begin{array}{l}\text { e-ISSN: } 2528-858 X \\
\text { doi: } 10.19159 / \text { tutad. } 935710\end{array}$ \\
\hline
\end{tabular}

\title{
Fizyografyadaki Değişimin Profil Gelişimine ve Toprak Özellikleri Üzerine Etkisi
}

\author{
Sinan DEMII ${ }^{1 *}$, Levent BAŞAYİĞİT \\ Isparta Uygulamalı Bilimler Üniversitesi, Ziraat Fakültesi, Toprak Bilimi ve Bitki Besleme Bölümü, Isparta, TÜRKİYE
}

\begin{abstract}
Geliș Tarihi/Received: 10.05 .2021
Kabul Tarihi/Accepted: 08.11.2021

ORCID ID (Yazar sırasma göre / by author order)
(1Dorcid.org//0000-0002-1119-1186 (D) orcid.org/0000-0003-2431-5763
"Sorumlu Yazar/Corresponding Author: demirsinan.07@gmail.com

Öz: Kayaların ve organik girdilerin ana materyale ve toprağa dönüştürülmesi, fiziksel, kimyasal ve biyolojik faktörler tarafindan kontrol edilen dinamik bir süreçtir. Bu süreçte ana materyal, iklim, topografya, organizma ve zaman oluşum faktörleri olarak bilinmektedir. Fizyografyadaki farklılıklarda diğer oluşum faktörlerinin etkisiyle toprak özelliklerinde değişkenliğe yol açmaktadır. Bu çalışmada, fizyografik değişkenliğin profil morfolojisine nasıl yansıdığı ve bu yansımanın toprak özelliklerinde istatistik olarak etkilerinin ortaya konması amaçlanmıştır. Değişen fizyografik birimleri (üst etek, alçak plato düzlüğü, alt etek) temsil etmek üzere güney -kuzey doğrultusu üzerinde dört toprak profilinin (PI, PII, PIII, PIV), morfolojik tanımlamaları yapılarak, horizon esasına göre alınan toprak örneklerinin bazı fiziksel ve kimyasal özellikleri belirlenmiștir. Ayrıca, toprak özelliklerindeki değișkenler bazı istatistiksel parametreler ile değerlendirilmiștir. Calıșma sonucunda, tüm profiller Lithic Xerorthent / Petrocalcic Leptosol olarak sınıflandırılmıştır. Üst ve alt eteklerdeki profiller benzer özelliğe sahip iken, alçak düzlükte yer alan profilin horizon derinliği ve kalınlığ 1 , toprak rengi, kireç içeriği, bünye ve su karakteristikleri yönünden farklılık gösterdiği belirlenmiştir. Bu çalışma ile toprak özelliklerindeki değişimin istatistiksel yaklaşımlarla değerlendirilmesi sonucu ilişkilerin daha net açıklanabileceği ortaya konmuştur.
\end{abstract}

Anahtar Kelimeler: Fizyografya, toprak taksonomisi, toprak özellikleri, toprak oluşumu, marn, entisol

\section{The Effect of Physiographical Change on Profile Development and Soil Properties}

\begin{abstract}
The transformation of rocks and organic inputs into parent material and soil is a dynamic process controlled by physical, chemical and biological factors. In this process, the parent material, climate, topography, organism and time are known as formation factors. The differences in physiography cause variability in soil properties with the effect of other formation factors. In this study; It is aimed to reveal how the physiographic variability is reflected in the profile morphology and the statistical effects of this reflection on soil properties. Morphological descriptions of four soil profiles (PI, PII, PIII, PIV) were made in the north-south direction to represent the varying physiographic units (shoulder, toeslope, backslope) and some physical and chemical properties of soil samples taken on the basis of the horizon were determined. In addition, the variables in soil properties were evaluated with some statistical parameters. As a result of the study, all profiles were classified as Lithic Xerorthent / Petrocalcic Leptosol. While the profiles on the upper and lower skirts have similar characteristics, it has been determined that the profile in the low plain differs in terms of horizon depth and thickness, soil color, lime content, texture and water characteristics. With this study, it has been revealed that the relationship can be explained more clearly as a result of the evaluation of the change in soil properties with statistical approaches.
\end{abstract}

Keywords: Physiography, soil taxonomy, soil properties, soil genesis, marn, entisol

': Sinan DEMIR, Organik Tarım alt alanında 100 / 2000 YÜKSEKÖĞRETIM KURULU Doktora Bursiyeri'dir. 


\section{Giriş}

Toprak, karasal ekosistemin ve tarımsal üretimin en önemli parçasıdır. Toprakların uygun şekilde kullanımı ve yönetilmesi için genel karakteristiklerinin bilinmesi gerekmektedir. Toprak oluşumu; hava, su, ana materyal ve organizmaların etkisiyle oluşan dinamik bir süreçtir. Toprakların oluşumunda doğal süreçlere müdahalelerin zor olduğu, yapay olarak üretimin mümkün olmadığı ve kaybedilmesi halinde yerine başka bir kaynağın kullanılamayacağı göz önünde bulundurulduğunda, bu dinamik faktörler ile ilişkilerinin ortaya konması oldukça önemlidir (Karacan ve ark., 2016). Jenny (1946), toprağ 1 oluşturan faktörleri; ana materyal, iklim, topografya, organizmalar ve zaman değişkenleri ile tanımlamıştır. Toprak özelliklerindeki değişkenlik bu faktörlerin bir fonksiyonu olarak açıklanabilir (Wilson ve ark., 2017; Tunçay ve ark., 2019). Bu önemli faktörlerden biri veya bir kaçı değiştiğinde, toprakların özelliklerinde farklılıklar ortaya çıkmaktadır. Özellikle kısa mesafelerde toprağın kimyasal, fiziksel ve morfolojik özelliklerindeki önemli farklılıkların mikro-iklim, topografya ve ana materyal arasındaki dinamik etkileşimle ilişkili olduğu bilinmektedir (Dengiz ve Başkan, 2010; Conforti ve ark., 2020). Daha geniş ölçekli alanlarda ise makroklima ve bitki örtüsünün etkisi daha önemlidir (Karaca ve ark., 2021).

Ayrışma, yerkabuğu yüzeyinde kayaların ve minerallerin fiziksel ve kimyasal değişimi olarak tanımlanmaktadır (Şenol ve ark., 2014). Mekanik ayrışma veya parçalanma olarak da bilinen fiziksel ayrışma, kaya ve minerallerin fiziksel olarak daha küçük parçalara ayrılmasını sağlayan olaylardır. Kimyasal ayrışma ise kayaçların bileşimindeki minerallerin ayrışması şeklinde tanımlanmaktadır. Kimyasal ayrışma süreçlerinin değerlendirilmesinde kullanılan endeksler, toprakta veya ana materyal üzerinde hareketli ve hareketsiz elementlerin oranlarının değerlendirilmesiyle topraktaki kimyasal ayrışmanın yoğunluğunu tahmin eder (Tunçay ve ark., 2019; Şenol ve ark., 2020a). Ayrıca hareketli toprak profilinin altında yatan saprolitin ayrışma durumunun bir ölçüsünü gösterir. Bu ayrışma süreçlerinde, fiziki etkenlerin ana materyal üzerinde nasıl bir değişkenliğe yol açacağının değerlendirilmesi toprak yönetimi açısından önemli bir faktördür. Toprak özellikleri; ana materyal, topografya, eğim, nemlilik ve bitki örtüsü durumuna bağlı olarak değişkenlikler göstermektedir (Dengiz ve Usul, 2018; Karaca ve ark., 2021). Özellikle, ana materyaldeki değişkenlikler, minerolojik ve morfolojik farklılıklardan kaynaklı olarak birçok toprak özelliğini etkilemektedir.
Toprak özelliklerindeki değişkenliğin toprak oluşumu ve gelişimi ile karşılaştırılmasında istatistiksel yöntemler uzun yıllardır kullanılmaktadır (Karahan ve ark., 2014; Sağlam ve Dengiz, 2015; Özyazıcı ve ark., 2015, 2016; Vasu ve ark., 2017a, 2017b; Çelik ve Dengiz, 2018; Owliaie ve ark., 2018; Alaboz ve ark., 2020). Çalışmalarda, toprak özelliklerinin değerlendirilmesinde kullanılan tanımlayıcı istatistikler, özelliklerin birbirleriyle olan ilişkilerinin ortaya konmasında değerlendirilen korelasyon katsayıları (Rasool ve ark., 2020; Sorokin ve ark., 2021) gibi yöntemler yaygın olarak incelenmektedir (Başayiğit ve ark., 2008; Dengiz ve Başkan, 2010; Sağlam, 2013; Dengiz ve Usul, 2018; Alaboz ve ark., 2020; Şenol ve ark., 2020b; Karaca ve ark., 2021; Polat ve ark., 2021).

Bu çalışmada; aynı iklim koşullarında, benzer arazi kullanım ve arazi örtüsü altında ve marn ana materyal üzerinde oluşan toprakların, fizyografik birimlerdeki farklılığa bağlı olarak, i) toprak özelliklerindeki değişkenliklerin istatistiksel yöntemler ile incelenmesi ve ii) toprak sinıflama sistemindeki taksonomik sinıfinın değerlendirilmesi amaçlanmıştır.

\section{Materyal ve Yöntem}

\section{1. Çalışma alanı ve bazı coğrafik özellikleri}

Çalışma alanı; Batı Akdeniz Bölgesi’nde Isparta ili Gönen ilçesi, Koçtepe (Fandas) köyü uzun alan mevkiinde 4196124.59-4196863.44 N kuzey enlemleri ile 276966.57-278093.06 E doğu boylamlar1 (WGS-1984, UTM-m, 36N zon) arasında yer almaktadır (Şekil 1). Bu alan, 1/25000 ölçekli topografik haritada Isparta M24-b2 paftasında Aladağ tepesinin güneyinde ve Uzunkıran tepesinin kuzeyindedir.

Çalışma alanını temsilen, Isparta (Merkez) Meteoroloji İstasyonu'ndan alınan ve 1990-2020 y1lları arasına ait meteorolojik parametrelere göre; yıllık ortalama yağış miktarı 602.48 mm olup, uzun yıllar verilerine göre, en yağışlı ay Aralık ayı (96.83 $\mathrm{mm})$, en az yağışlı ay ise Ağustos ayı (14.37 mm) olarak kayıtlara geçmiştir. Uzun yıllar yıllık ortalama sicaklık $12.54{ }^{\circ} \mathrm{C}$ olup, en yüksek aylık ortalama sicaklık Temmuz ayında $24.01{ }^{\circ} \mathrm{C}$, en düşük sicaklık ise Ocak ayında $1.72{ }^{\circ} \mathrm{C}$ olarak kaydedilmiştir (Anonim, 2021). Çalışma alanının toprak nem rejimi xeric, sicaklık rejimi ise mesic olarak tanımlanmıştır (Şenol ve ark., 2020b).

Çalışma alanı Koçtepe formasyonu sınırları içerisinde yer almaktadır. Koçtepe formasyonu altta konglomeratik-breşik bir taban ile başlayıp, üste doğru ince-orta katmanlı, yer yer böbreğimsi ayrışmalı, pelajik marnlarla devam eder 

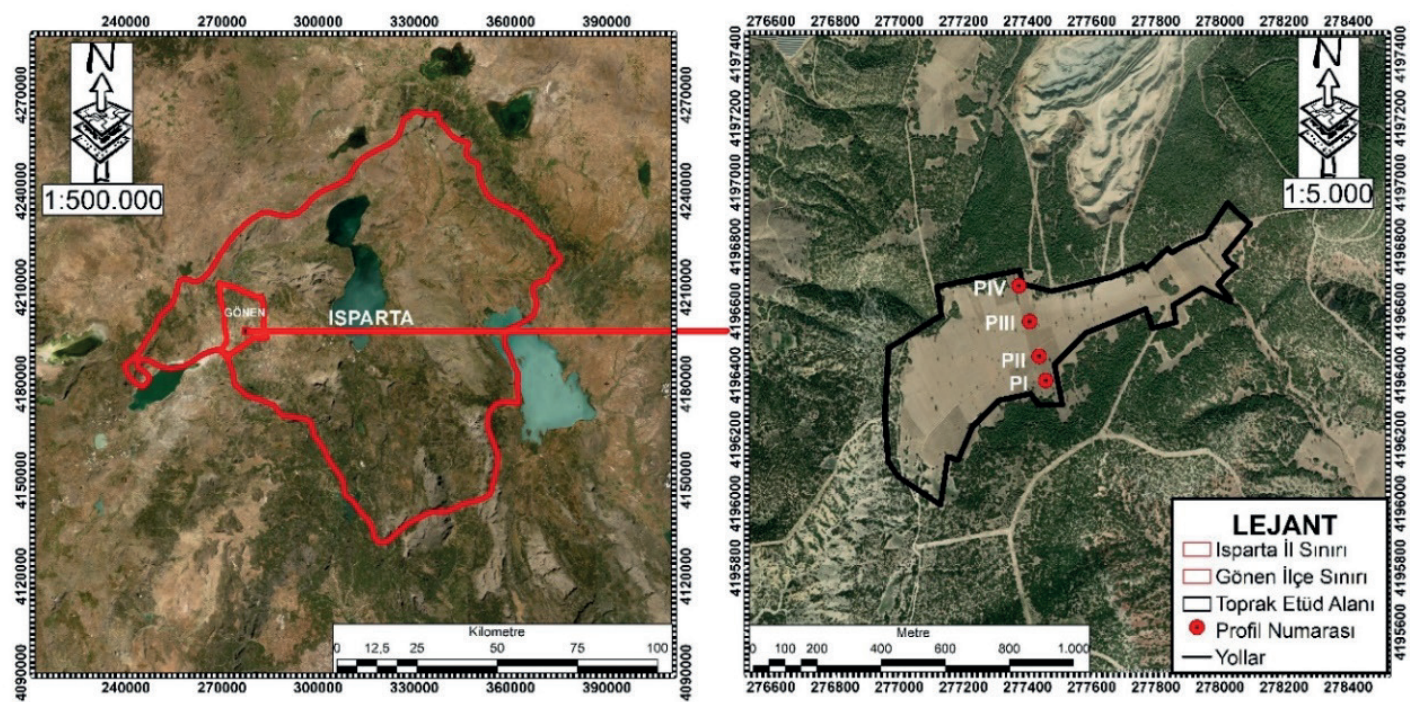

Şekil 1. Çalışma alanı konumu

Figure 1. Study area location

(Yalçınkaya, 1989). Kırmızı renkli çamurtaşları ile temsil edilen birim; çok ince (1-2 cm), orta kalınlıkta $(5-10 \mathrm{~cm})$ ince taneli kumtaşı ara tabakaları da içermektedir. Yaşı Orta-Üst PaleosenAlt Eosen olarak belirlenmiştir (Karaman ve ark., 1988; Y1ldız ve Toker, 1991; Görmüş ve Karaman, 1992).

Çalışma alanının bulunduğu bölgede yaygın arazi kullanım türü kuru tarım olup, çevresinde makiler bulunmaktadır. Corine (2018)'e göre, sulanamayan ekilebilir alan 24.2 hektar (\% 72.01), iğne yapraklı ormanlar 4.9 hektar $(\%$ 14.61) ve belirli dönemlerde ağaç kesiminin yapıldığı koru veya baltalık arazilerin tekrar ağaçlandırılmış kesimlerine karşılık gelen bitki değişim alanları 4.5 hektar (\% 13.38)'dir.

\subsection{Toprak örneklerinin alınması ve sınıflandırma}

Çalışma alanı içerisinde 4 farklı profil (PI, PII, PIII ve PIV) tanımlanmış ve değerlendirilmiştir (Şekil 2). Farklı fizyografik birime (üst etek, alçak plato düzlüğü, alt etek) sahip olan profillerden horizon esasına göre 14 adet bozulmuş ve bozulmamış toprak örnekleri alınarak morfolojik tanımlamalar yapılmıştır. Profil tanımlamaları Anonymous (2014)'a göre, horizonların isimlendirilmesi ve siniflandirılması ise Anonymous (2015)'a göre yapılmıştır.

\subsection{Toprakların fiziksel ve kimyasal analiz yöntemleri}

Tane büyüklük dağılımı hidrometre yöntemi ile Bouyoucos (1951)'a göre, toprak rengi kuru ve nemli halde Munsel renk 1skalası kullanılarak Anonymous (2004)'a göre belirlenmiştir.
Topraklara ait $\mathrm{pH}$ ve elektriksel iletkenlik (EC) değerleri potansiyometrik, kireç içerikleri Scheibler kalsimetresi ile volumetrik olarak Kacar (2009)'a göre tespit edilmiştir. Toprakların organik madde içerikleri değiştirilmiş Walkley-Black yöntemi ile Jackson (1958)'a göre, katyon değişim kapasitesi (KDK) $1 \mathrm{~N} \mathrm{NH}_{4} \mathrm{OAc}(\mathrm{pH}=7.0)$ yöntemi (Peech ve ark., 1947) kullanılarak belirlenmiştir. Hidrolik iletkenlik (HI) ve hacim ağırlığı (HA), Hanay ve ark. (1996)'na göre; tarla kapasitesi (TK), solma noktası (SN) ve faydalı su (FS) içeriği Burt (2014)'e göre saptanmıştır. Toprakların bor (B) içerikleri Wolf (1971)'a göre sıcak su ile ekstraksiyon işlemi yapılarak İndüktif Eşleşmeli Plazma (Inductively Coupled Plasma, ICP) cihazında tespit edilmiştir.

\section{4. İstatistiksel analiz yöntemleri}

Profillerden elde edilen toprakların fiziksel ve kimyasal özelliklerine ait tanımlayıcı istatistiksel analizleri (minimum, maksimum, ortalama, standart sapma, varyasyon katsayısı, çarp 1 klık, basıklık) MINITAB paket programları kullanılarak yapılmıştır. Toprak özelliklerinin ilişkilerinin değerlendirilmesinde korelasyon (Pearson) analizi kullanılmıştır. Pearson korelasyonu, verilerin normal dağılım göstermesi durumunda tercih edilen bir yöntem olup iki değişkenler arasındaki ilişkinin yönünü ve gücünü belirtmektedir (Pearson, 1900; Benesty ve ark., 2009; Alaboz ve ark., 2021a, 2021b). Farklı fizyografik birimlere bağlı toprak özelliklerindeki minimum, maksimum ve ortanca değerlerdeki değişim aralıkları kutu grafiği (boxplot) görselleri ile belirtilmiştir (Tukey, 1977). Toprak özellikleri arasındaki korelasyon matrislerinin belirlenmesinde $\mathrm{R}$ programları kullanılmıştır. 


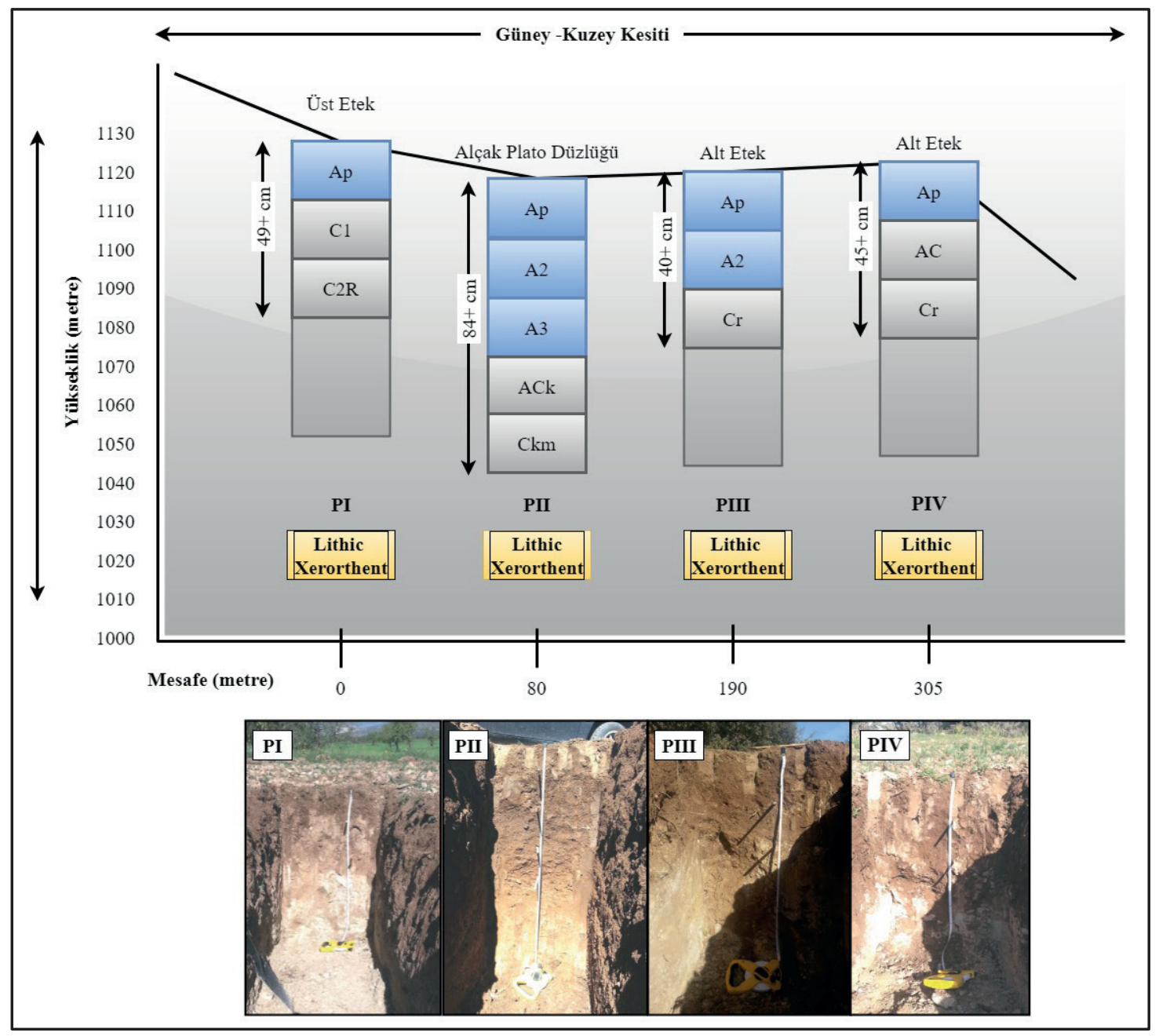

Şekil 2. Güney-kuzey doğrultusunda yer alan farklı topografik pozisyonda bulunan profiller Figure 2. Profiles in different topographic positions in the south-north direction

\section{Bulgular ve Tartışma}

\subsection{Profillerin morfolojik özellikleri ve sinıflandırılması}

Profiller, üst etek (PI), alçak plato düzlüğü (PII), alt etek (PIII ve PIV) fizyografik birimleri üzerinde yer almıştır. Çalışma alanı çevresinde yüksek yamaçların bulunması zamanla su erozyonu gibi doğal süreçleri beraberinde getirmekte ve alçak plato düzlüklerinde birikimlere neden olmaktadır. Topraklar, esas itibariyle yağış ve eğim etkisi ile farklı eğim gruplarında olan materyallerden oluştuğu için Koçtepe serisi olarak tanımlanmıştır. Alanının doğu yönünde doğal eğimden kaynaklı eğimin azaldığı yerlerde ince bünyeli materyal birikmiştir. Profillerin ana materyalleri marn olarak belirlenmiştir.

Toprak profillerinden PII, eğim ve aluviyal birikinti üzerinde oluşmuştur (Tablo 1). PI ve PIV ise topografya etkisinin görüldüğü profillerdir. Eğim etkisi ile toprak profilinde litolojik kesinti

Tablo 1. Toprak profillerinin bazı özellikleri

Table 1. Some properties of soil profiles

\begin{tabular}{ccccccccc}
\hline Profil & \multicolumn{2}{c}{ Koordinatlar } & Ana & Yükseklik & Fizyografya & $\begin{array}{c}\text { Eğim } \\
\text { konumu }\end{array}$ & $\begin{array}{c}\text { Eğim } \\
(\%)\end{array}$ & $\begin{array}{c}\text { Arazi örtüsü } \\
\text { / arazi } \\
\text { kullanımı }\end{array}$ \\
\hline PI & 277457 & 4196383 & Marn & 1128 & Üst etek & Orta eğimli & $6-12$ & Kuru tarım \\
\hline PII & 277436 & 4196459 & Marn & 1115 & $\begin{array}{c}\text { Alçak plato } \\
\text { düzlüğü }\end{array}$ & Düz & $0.5-2$ & Kuru tarım \\
\hline PIII & 277407 & 4196567 & Marn & 1117 & Alt etek & Hafif eğimli & $2-6$ & Kuru tarım \\
\hline PIV & 277373 & 4196679 & Marn & 1119 & Alt etek & Hafif eğimli & $2-6$ & Kuru tarım \\
\hline
\end{tabular}


farklılaşmıştır. Toprak oluşumu incelendiğinde PI ve PIV profilleri diğer horizonlara göre daha az gelişim göstermiştir. PIII profilinin hafif eğimli topografyada olması, toprak gelişiminin PII profilinden de az düzeyde olduğunun bir sebebi olarak değerlendirilmiştir. PII, yağışlar ile çevreden taşınan kaba materyalin, ana materyalden pedojenik olarak ara katman oluşumu ile ayrılmıştır. Bu durum, PII'nin fizyografik durumun daha fazla etkisi altında olabileceğini göstermektedir.

Çalışma alanında açılan dört profil, profil boyunca kireçli olup profillerde belirgin kireç yıkanması belirlenmemiştir. Profillerde renk 7.5YR ile 10YR arasında değişmekte olup genelde üst horizonlardan ana materyale doğru yüksek value değerlerine sahiptir. Yüzey horizonlarında value değerleri özellikle organik maddenin etkisiyle düşük olmasına karşın, ana materyalin karbonat içeriği zengin marn olması, derinlere doğru özellikle C horizonlarında daha yüksek value değerlerine neden olmuştur. PII profili dışındaki profillerde seyreltik hidroklorik asit $(\mathrm{HCl})$ ile $\mathrm{C}$ horizonlarında çok güçlü reaksiyon tespit edilmiştir. PII profilinde ana materyal etkisi dışında kiltaşı ana materyalinden taşınım etkisi görülmekte ve çözünen karbonatın alt horizonlara taşındığı tespit edilmiştir. Topraklar kil ve silt içeriğine bağlı olarak, genellikle kuru iken sert, sslak iken yapışkan ve plastik özellik göstermektedir. Profilin Ap horizonu dişında çok yüksek kil içeriğine (\% 63.3) sahip olması, kıvam özelliklerini de etkilemekte ve kuru iken çok sert hale dönüşmektedir. Bu topraklarda yazları derin çatlaklar görülmediği ve kayma yüzeyleri bulunmadığı için vertik özellik göstermemiş ve bir yüzey altı tanı argillic horizonu tanımlanmamıştır (Tablo 2).

Profiller içerisinde, yüzey altı tanı horizonları belirlenmemiştir. Toprakların oluşum süreçlerine bağl1 olarak yüzey üstü ve yüzey alt1 tanı horizonlarının varlığına veya yokluğuna göre topraklar Entisol ordosunda belirlenmiştir. Topraklar A-C horizonlu profil içerisinde tanecik boyutu profil içindeki tüm horizonlarda \% 35 'ten daha az kaya parçalarına sahip olması ve diğer Entisol alt ordosu özelliklerini karşılamadığ orthent alt ordosuna atanmıştır.

Profiller xeric toprak nem rejimi içerisinde olmasından Xerorhent büyük grubuna atanmıștır. Ana materyal üzerinde A horizonu gelişim göstermesi ve mineral toprak yüzeyinin $50 \mathrm{~cm}$ içerisinde olması nedeniyle profiller lithic olarak tanımlanmışlardır. Horizon ve katmanlarda pedojenik açıdan belirgin farklılaşma belirlenmemiştir. Kil, mika vb. kil tipi birikimi olması ve düşük KDK içeriği nedeniyle diğer yüzey altı horizon şartlarını sağlamamaktadır. Marn ana materyal üzerinde oluşan topraklarda karbonat içeriği profil içerisinde alt horizonlara doğru artmaktadır. PII profilinde kaba malzeme ve yüksek pH nedeni ile kirecin alt horizonlarda birikimi görülmektedir. $\mathrm{Bu}$ nedenle, ana materyalde kaba iskelet malzemesi arasında sertleşme olduğu belirlenmiştir. Hacim ağırlığının düșük olması başka yüzey altı horizon sınıfını karşılamamaktadır.

Çalışma alanındaki topraklar, pedojenik horizon oluşumunun oldukça zayıf olmasından dolayı genç topraklar olarak nitelendirilmiştir. Anonymous (2014)'a göre PI, PII, PIII ve PIV profilleri Entisol ordosunda, Orthent altordosunda, Xerorthent büyük grubunda, Lithic Xerorthent alt grubunda belirlenmiştir. Anonymous (2015) toprak sinıflamasına göre ise, PI, PII, PIII ve PIV profillerinin temsil ettiği topraklar Petrocalcic Leptosol olarak sınıflanmıştır.

\subsection{Toprak özellikleri ve istatistiksel değerlendirmeler}

Çalışma alanındaki her bir profilde yer alan toprakların temel fiziksel ve kimyasal özellikleri Tablo 3'te sunulmuştur. Solum derinliği, iklim etkisinin derecesine ve toprak oluşum sürecinin aşamasına bağlı olarak 21 ile $64 \mathrm{~cm}$ arasında değişmektedir. Tüm profillerin horizonlarında, topraklar kuvvetli derecede alkalin reaksiyonlu ( $\mathrm{pH}=8.5-9.0)$ ve çözünebilir tuz içerikleri (EC) düşük olarak belirlenmiştir. PI, PIII ve PIV profilleri için baskın toprak tekstür sınıfı killi tın olarak tespit edilmiştir. PIII profilinde toprakların kil içerikleri \% 29.6-43.1 arasında değișmekte olup, PII profilinin tekstür sınıfı kil ve killi tın'dır. PII profili, \% 33.7 ile \% 63.3 arasında değişen oranda en yüksek kil içeriğine sahip profil olarak belirlenmiştir (Tablo 3). Eğimin azaldığı noktalarda kil içeriğinin artması, taşınma ve birikimin bir sonucu olabilmektedir.

Toprak KDK değeri, PII profilinde en yüksek olup, 25.637 ile 46.372 cmolc $\mathrm{kg}^{-1}$ arasinda değişmektedir. PII profilinde birikimlerin etkisiyle kil içeriği yüksek olup, buna bağlı olarak KDK da yüksek bulunmuştur. Solumda düşük kireç içeriği çözünme ve yıkanmanın bir göstergesidir. Farklı fizyografyadaki profillerin horizonlarında KDK içerikleri düşey horizon diziliminde düşüş göstermektedir. PII profilinde kil miktarı yüzey altı horizonunda artış göstermiş, daha sonra diğer profillerde de olduğu gibi derinliğe bağlı azalma sergilemiştir. KDK toprakların fizyografik birimlerine ve profil gelişimine göre değişmektedir. Farklı profillerdeki özellikler, iklim ve ana materyel arasındaki dinamik etkileşimin bir sonucu olarak değişmektedir (Dengiz, 2010; Şenol ve ark., 2020a). 

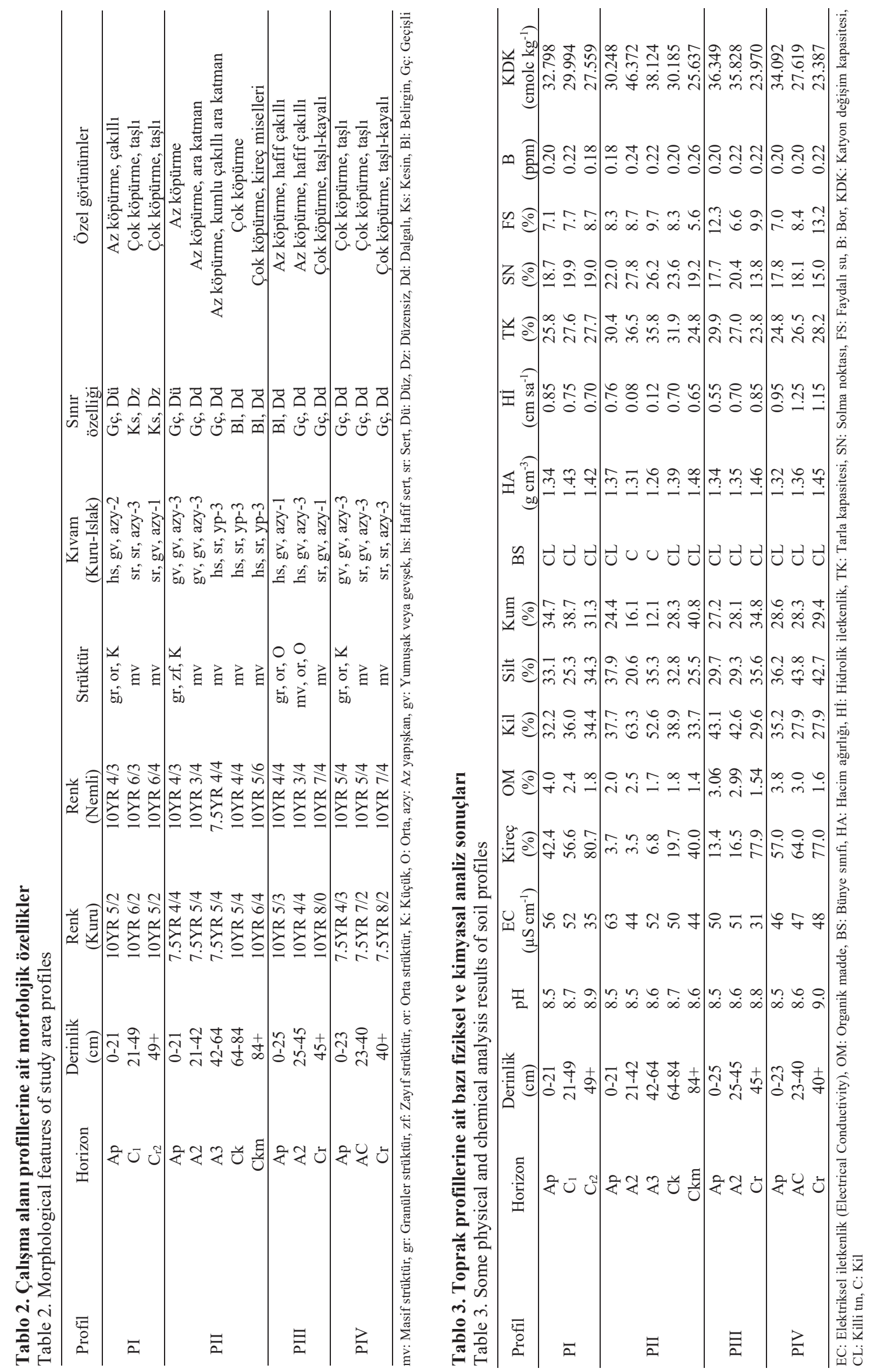
Yarı kurak bölgede yer alan çalışma alanında organik madde birikimi düşük, toprakların yüksek rakımda olması ve kireç içermesinden dolayı organik maddenin kaybı taban arazilere göre daha düşük seyretmiştir. Çalışma alanındaki tüm profiller için, organik madde içeriği yüzey horizonlarda \% $\quad 2-4$ arasında iken, yüzey alt1 horizonlarda daha düşük düzeydedir (\% $1.4-1.8)$ (Tablo 3). Yüzey altı topraklarda düşük organik madde seviyeleri, organik maddenin hizlı ayrışmasına ve mineralleşmesine bağlanabilir. Yapılan çalışmalarda, kurak ve yarı kurak bölgelerde organik madde birikiminin az olduğu ve toprak işlemeyle birlikte organik madde içeriğinin hızla bozularak kaybolduğu belirtilmiştir (Dengiz ve Usul, 2018). PII profilinin A2 horizonunda, organik maddenin parçalanma hızı artan kil içeriğine ve toprak işleme katmanının olmamasına bağlı olarak azalmaktadır. PII profilinde ara katman bulunmasından ve organik maddenin düșey hareketinden dolay1 $\mathrm{Ck}$ horizonunda $\mathrm{A} 3$ horizonuna göre organik madde miktarında \% 0.1'lik bir artış görülmektedir. $\mathrm{Bu}$ profilde ana materyal yanında fizyografya etkisi ile eğimin düşmesine bağlı olarak kil birikimi meydana gelmiş ve toprak oluşumu etkilenmiştir. Kilin toprak işleme etkisi ile birlikte yağış ile alt horizonlara taşınmasından kaynaklanmaktadır. Azlan ve ark. (2012) tarafından, killi ve kil içeriği yüksek topraklarda organik maddenin parçalanma hızının daha yavaş olduğu bildirilmiştir.

Toprakların hacim ağırlığı değerleri 1.26-1.48 g $\mathrm{cm}^{-3}$ aralıklarında değişim göstermiştir. PII profilinde Ap horizonun varlığ tarımsal faaliyetlere bağlı olarak toprak işleme katmanlarının bir göstergesidir. Yoğun tarla trafiğine bağlı olarak toprak sıkışması meydana gelmekte ve hacim ağırlığı değerlerinde artışlar tespit edilmektedir. PII profilinde de bu açıkça gözlenmekte olup hacim ağırlığ değeri en yüksek bu profilde belirlenmiştir. Yüzey altı horizonlarda hacim ağırlığı değerleri daha düşük olup, 1.32-1.37 $\mathrm{g} \mathrm{cm}^{-3}$ arasında değişim sergilemiştir (Tablo 3).

Profillerin kireç $\left(\mathrm{CaCO}_{3}\right)$ içeriği farklılık göstermektedir. Topraklar, kireç içeriği yüksek ana materyaller üzerinde oluşmuş olsa da, PII ve PIII profilinin Ap ve A2 horizonlarında kireç içeriği (\% 3.5-\% 16.5) düşük olarak belirlenmiştir. En yüksek kireç içeriği (\% 80.7) PI profilinin $\mathrm{C}_{\mathrm{r} 2}$ horizonunda tespit edilmiştir. PI, iklim ve fizyografyanın etkisi ile malzeme birikiminin görüldüğü ve en düşük kireç içeriğine sahip profildir. Marn ana materyali üzerinde topraklar kireçli ve çok fazla kireçli sınıflarında yer almaktadır. PII yüzey horizonlarında kireç içeriği düşmektedir (Tablo 3). Kireç içeriğinin eğimin azaldığı yerde birikmesi beklenirken, fizyografik birimdeki yüzey horizonlarında kireç içeriği düşmektedir. Bunun nedeni yüzeyden taşınan ana materyalin kiltaşı olması kaynaklıdır. Çözünen kireçtaşı ve marn taşınımı çok düşük olması artan kil içeriği ve düşük kireç içeriğini desteklemektedir (Colombo ve ark., 2015; Çelik ve Dengiz, 2018). Yarı kurak ve kurak bölgelerde topraklar kalkerli ve daha kaba tekstüre sahiptir (Tunçay ve ark., 2019).

Toprakların bor içeriği, profillere ve horizonlara bağlı olarak önemli seviyede değişkenlik sergilememiştir. Kil ve silt içeriğine bağlı olarak tüm profillerde tarla kapasitesi, solma noktası ve faydalı su değerleri yüksektir. Hidrolik iletkenlik artan kil içeriğine bağlı olarak alt horizonlarda azalmaktadır. Azalan hidrolik iletkenlik şiddetli yağışlarda yüzey akışına geçerek eğim doğrultusunda, toprak taşınımına ve fizyografyaya bağlı olarak PI, PIII ve PIV profillerinde toprak oluşumunu sınırlayıcı faktör olarak görülmektedir (Tablo 3).

Toprak özelliklerine ait tanımlayıcı istatistikler Tablo 4'te belirtilmiştir. Toprak özeliklerindeki değişimlerin açıklamasında önemli bir gösterge olarak kabul edilen değişkenlik katsayısı, düşük $(<\% 15)$, orta (\% 15-35) ve yüksek ( $>\% 35)$ olarak sinıflandırılmaktadır (Wilding, 1985). Buna göre, çalışma alanına ait toprak özelliklerinden $\mathrm{pH}, \mathrm{HA}$, TK ve B düşük; EC, kil, silt, kum, SN, FS ve KDK orta; kireç, organik madde ve HI yüksek değişkenlik özellikleri göstermektedir (Tablo 4). Normal dağılımı test etmek için kullanılan çarpıklık ve basıklık katsayıları incelendiğinde; her iki katsayının da normal dağılımdan anlamlı düzeyde farklılık göstermemesi ve -1 ile +1 aralığında olması beklenmektedir (Pearson, 1900). Çarpıklık katsayısının negatif olması sola, pozitif olması sağa çarpıklığı gösterirken; basıklık katsayısında ise negatif, eğrinin normale göre daha basık, pozitiflik daha dik olduğunun göstergesidir (Alaboz ve ark., 2020, 2021b). Normal dağılıma en uzak özellik pH ve kil olarak belirlenmiştir. pH ve kil özellikleri sağa çarpık bir dağılım gösterirken, diğer özellikler normale yakın bir dağılım sergilemiştir. Toprakların kil ve EC içeriklerinin dağılımlarında eğri normale göre daha dik iken, kireç içeriklerindeki bu dağılım daha basıktır. Diğer özelliklerde dağılımın basıklık durumu normale daha yakın olarak belirlenmiştir (Tablo 4).

Kars ve Ekberli (2019) tarafından Çarşamba Ovası'nda işlenen tarım alanlarının bazı fiziksel ve kimyasal toprak özelliklerinin incelenmesi amacıyla yapılan çalışmada, çalışma alanının toprak özelliklerinde ortalama KDK kapasitesi $40.52 \mathrm{cmol} \mathrm{kg}^{-1}$ ile yüksek bulunmuştur. Başayiğit ve ark. (2008) tarafindan Isparta ili Atabey Ovası'nda yapılan çalışmada, yüzey örneklerinde 
Tablo 4. Profillere ait toprakların fiziksel ve kimyasal özelliklerine ait tanımlayıcı istatistikleri Table 4. Descriptive statistics of the physical and chemical properties of the soils of the profiles

\begin{tabular}{|c|c|c|c|c|c|c|c|}
\hline Toprak özellikleri & Ortalama & $\begin{array}{c}\text { En } \\
\text { düşük }\end{array}$ & $\begin{array}{c}\text { En } \\
\text { yüksek }\end{array}$ & $\begin{array}{c}\text { Standart } \\
\text { sapma }\end{array}$ & $\begin{array}{c}\text { Değişkenlik } \\
\text { katsayis1 } \\
(\%)\end{array}$ & Çarpıklık & Basıklık \\
\hline $\mathrm{pH}$ & 8.64 & 8.50 & 9.00 & 0.16 & 1.86 & 1.13 & 0.48 \\
\hline $\mathrm{EC}\left(\mu \mathrm{S} \mathrm{cm}^{-1}\right)$ & 47.79 & 31.00 & 63.00 & 8.00 & 16.74 & -0.46 & 1.10 \\
\hline $\mathrm{CaCO}_{3}(\%)$ & 39.94 & 3.50 & 80.70 & 29.13 & 72.93 & 0.09 & -1.65 \\
\hline Organik madde (\%) & 2.40 & 1.40 & 4.00 & 0.85 & 35.49 & 0.67 & -0.74 \\
\hline Kil $(\%)$ & 37.12 & 27.90 & 63.30 & 9.26 & 24.96 & 2.00 & 5.26 \\
\hline Silt (\%) & 33.01 & 20.60 & 43.80 & 6.52 & 19.75 & -0.17 & -0.19 \\
\hline Kum $(\%)$ & 28.77 & 12.10 & 40.80 & 7.76 & 26.97 & -0.69 & 0.77 \\
\hline Hacim ağırlı̆̆ $1\left(\mathrm{~g} \mathrm{~cm}^{-3}\right)$ & 1.38 & 1.26 & 1.48 & 0.06 & 4.63 & 0.02 & -0.72 \\
\hline Hidrolik iletkenlik $\left(\mathrm{cm} \mathrm{h}^{-1}\right)$ & 0.72 & 0.08 & 1.25 & 0.32 & 45.00 & -0.62 & 0.78 \\
\hline Tarla kapasitesi (\%) & 28.62 & 23.80 & 36.50 & 3.91 & 13.66 & 0.96 & 0.19 \\
\hline Solma noktas $1(\%)$ & 19.94 & 13.80 & 27.80 & 3.89 & 19.51 & 0.62 & 0.23 \\
\hline Faydalı su (\%) & 8.68 & 5.60 & 13.20 & 2.09 & 24.03 & 0.94 & 0.80 \\
\hline Bor (ppm) & 0.21 & 0.18 & 0.26 & 0.02 & 10.31 & 0.62 & 0.66 \\
\hline $\mathrm{KDK}\left(\mathrm{cmolc} \mathrm{kg}^{-1}\right)$ & 31.58 & 23.39 & 46.37 & 6.26 & 19.81 & 0.87 & 0.97 \\
\hline
\end{tabular}

ortalama KDK değeri ve ortalama EC değerleri çalışma ile uyumlu sonuçlar sergilemiştir. Çalışma alanındaki toprakların topografik karakteristiklerindeki farklılıklar toprak özelliklerindeki değişim aralığının geniş olmasının bir sebebidir. $\mathrm{Bu}$ değişkenlik varyasyon katsayısının düşük, orta ve yüksek seviyelerde belirlenmesine yol açmıştır. Yapılan bazı çalışmalarda, parsel ve tarım alanı ölçeğinde toprak özelliklerinin incelenmesi durumunda toprak özelliklerinin normal dağılım sergilemediği ve verilerin değerlendirilmesinde normalize edilmesi gerektiği belirtilmektedir (Vasu ve ark., 2017a; Hu ve ark., 2019).
Farklı fizyografik birimlerde oluşum gösteren topraklarda, özellikle taşınan materyallerdeki değişkenliklere bağlı olarak toprak özelliklerinin değerleri geniş dağılım sergileyebilmektedir (Dengiz, 2010; Alaboz ve ark., 2019, 2021a). Uzun yıllar tarımsal üretimin gerçekleştiği çalışma alanını temsilen farklı fizyografik birimlerde incelenen toprak özelliklerine ait değişim aralığının boxplot grafiği Şekil 3'te belirtilmiştir. Değişim aralığı, topografik yapı nedeniyle toprak gelişiminin zayıf olması ve üst horizonlardaki materyalin taşınması ile alt horizonlardaki ana materyal etkisinin fazla olmasından dolayı genişlemektedir. EC değeri toprak oluşumun en zayıf olduğu ve en sığ toprak

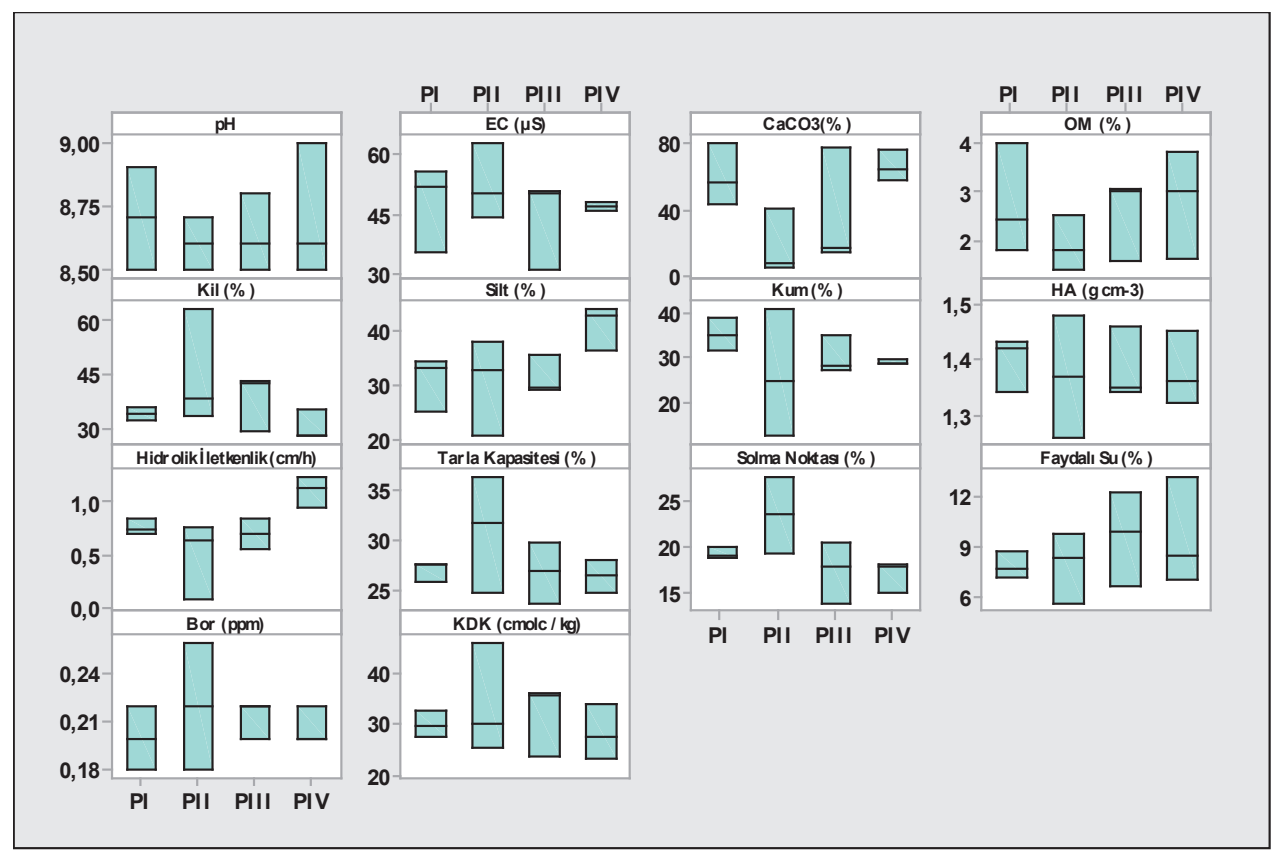

Şekil 3. Toprak özelliklerinin profil içerisindeki dağılımı

Figure 3. Distribution of soil properties within the profile 
gelişimi olan PIV profilinde dar bir değişim aralığ1 sergilemektedir. Alaboz ve ark. (2019) tarafından Isparta ilinde kuru tarım alanlarında yapılan çalışmada, yüzey topraklarının tuz içeriğinin düşük olduğu ve değişim aralığının dar olduğunu belirtilmiştir. EC için en geniş değişim aralığı alt etek fizyografyadaki PIII profilinde belirlenmiştir. Benzer durum kireç içeriği için de geçerlidir. Profillerin kil, silt, kum, HA, Hİ, TK, SN, B ve KDK içeriklerinde değişim aralığı en geniş PII profilinde belirlenmiştir (Şekil 3).

Marn ana materyali üzerinde oluşan profillerden alınan toprak örneklerinin fiziko-kimyasal özellikleri arasındaki korelasyon katsayıları belirlenmiştir. $\mathrm{Bu}$ analiz sonucunda istatistiksel olarak anlaml1 (***: $\mathrm{p}<0.001, \quad * *: \quad \mathrm{p}<0.01$, *: $\mathrm{p}<0.05)$ korelasyonlar bulunmuş ve sonuçlar Şekil 4'te sunulmuştur. Şekil 4'te pozitif korelasyon değerleri mavi renk ve tonları ile negatif korelasyon kırmızı renk ve tonları ile gösterilmiştir. En yüksek pozitif korelasyon kil ile KDK $\left(\mathrm{r}=0.91^{* * *}\right)$ arasinda belirlenmiştir. En yüksek negatif korelasyon kil ile Hİ $\left(r=-0.92^{* * *}\right)$ arasında bulunmuştur. Hacim ağırlıği ile kum arasında pozitif korelasyon $\left(\mathrm{r}=0.80^{* * *}\right)$, kil ile negatif korelasyon $\left(\mathrm{r}=-0.65^{* *}\right)$ tespit edilmiştir. Faydalı su içeriği ile $\mathrm{pH}$ arasında pozitif yönlü korelasyon $\left(\mathrm{r}=0.44^{*}\right)$ belirlenirken, diğer toprak özellikleri ile arasında korelasyon katsayısı oldukça düşük tespit edilmiştir. Kil içeriği ile SN arasinda pozitif korelasyon $\left(\mathrm{r}=0.85^{* * *}\right)$ bulunmuştur (Şekil 4). Sağlam (2013) tarafından da benzer sonuçlar ortaya konulmuştur. Toprakların TK ve solma noktasındaki nem içeriklerini tekstür, organik madde ve strüktür etkilemektedir. Tane büyüklügünün küçülmesi, artan organik madde içeriği ve strüktürün iyileşmesi, nem miktarını ve faydalı su kapasitesini arttırmaktadır (Karahan ve ark., 2014; Alaboz ve ark., 2019, 2021a).

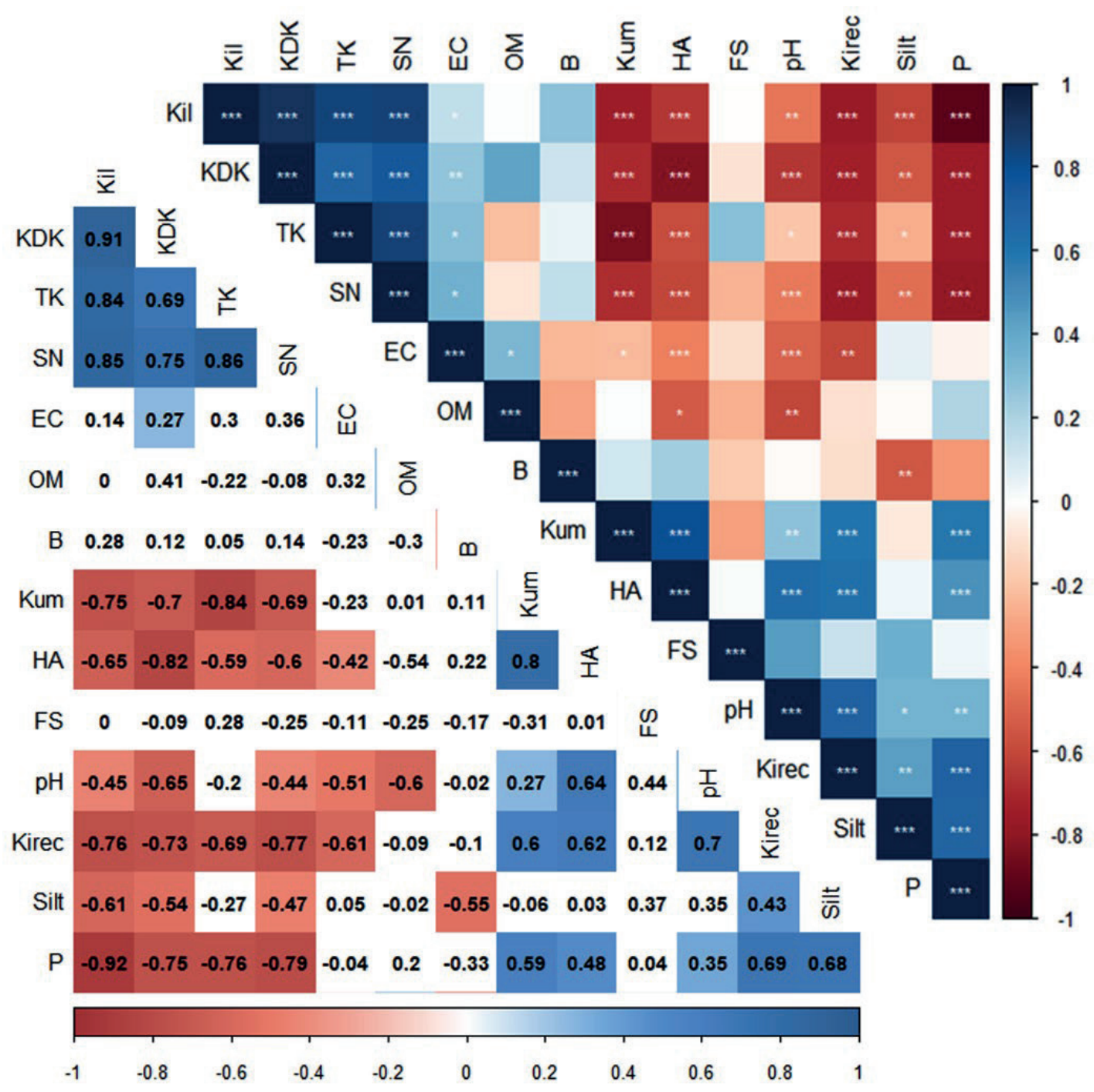

Şekil 4. Profillerin fiziko-kimyasal özelliklerinin korelasyon analizi

Figure 4. Correlation analysis of physico-chemical properties of profiles 
Profillerde tanımlanan horizonlarda HA, kum içeriği ile pozitif yönlü korelasyon sergilemiştir. Bu nedenle farklı fizyografyada açılan profillerdeki horizonlarda artan kum içeriği ile HA artış göstermektedir. Kil içeriği ve Hİ arasında (r= -0.92) yüksek korelasyon belirlenmiştir (Şekil 4). Artan kil içeriği hidrolik iletkenliği düşürmekte ve suyun düşey hareketini kısıtlamaktadır. Farklı fizyografik birimlerde yüzey akışın artması toprak gelişimini etkilemektedir (Sağlam, 2013). Düşük Hİ özelliği gösteren bölgelerde, yağış ve eğimin etkisi ile eğimin azaldığı alanlarda birikimlerin meydana gelmesi beklenilen bir durumdur. Taşınmaya bağlı profil içerisindeki toprak oluşumu ve gelişimi olumsuz yönde etkilenmektedir.

Profillerde organik madde miktarı TK ve SN kapasitesini arttırmaktadır. Buda FS içeriğini arttırmakta ve strüktür oluşumunu geliştirmektedir (Karahan ve ark., 2014; Alaboz ve ark., 2019). PII profilinde artan kil içeriği ile birlikte KDK artmaktadır. Ayrıca elde edilen KDK'daki artış organik madde miktarının Ap horizonunda \% 4 miktarına çıkması ile ilgili olarak değerlendirilmiştir. KDK ve organik madde arasında pozitif yönlü $\left(\mathrm{r}=0.41^{*}\right)$ istatistiksel olarak önemli seviyede ilişki belirlenmesi bunun bir sonucudur.

Yapılan toprak etüt çalışması ile farklı fizyografik birimler üzerinde oluşan toprakların fiziksel ve kimyasal özellikleri arasında önemli ilişkiler olduğu belirlenmiştir. Ayrıca toprak oluşumuna etki eden ana materyal ve topografya etkisi toprak oluşumu ve gelişimini etkilediği sonucu ortaya konulmuştur. Owliaie ve ark. (2018) İran'da farklı fizyografyaya sahip dokuz profilin fiziko-kimyasal analizleri, kil minerolojisi ve mikromorfolojik çalışmaları sonucunda, topografya ve ana materyalin, bölgedeki toprak olușumunu etkileyen iki faktör olduğunu belirtmişlerdir. Vasu ve ark. (2017b) Hindistan'da toprakların pedojenik süreçlerini araştırdıkları çalışmada, belirli toprak özellikleri, yüzey ve yüzeyaltı horizonları, arazi kullanımı arasındaki ilişkiler, baskın pedojenik süreçler, mevcut toprak özellikleri, topografya ve verim arasındaki etkileșimi ortaya koymada önemli olduğunu rapor etmişlerdir. Marn ana materyali üzerinde gelişen toprakların, diğer ince taneli topraklardaki düşey davranış yetersizliğinden, yüksek miktarda alçıtaşı ve düşük smektit içeriği hidrolik iletkenlik ve erozyonu arttırıcı etkiye sebep olmaktadır. Birçok çalışmada, toprakların gelişimi ve oluşumu üzerine yağış ve fizyografya etkisinin belirleyici unsur olduğu belirtilmiş (Dengiz ve Başkan, 2010; Owliaie ve ark., 2018; Conforti ve ark., 2020; Dedeoğlu ve ark., 2020; Alaboz ve ark., 2021b); literatürdeki bu bulgular, yapılan bu çalışmadan elde edilen sonuçları desteklemiştir.

\section{Sonuçlar}

$\mathrm{Bu}$ çalışma sonucunda; incelenen profillerdeki topraklar, morfometrik yaklaşımla benzer bulunmuş ve Toprak Taksonomisi'ne göre Lithic Xeroorthent, FAO sinıflamasina göre Petrocalcic Leptosol olarak sınıflanmıştır. Toprak örneklerinde yapılan analizlerin istatistik değerlendirmesi sonucu, en geniş değişim aralığı PII profilinde belirlenmiştir. Fizyografik değişime bağlı toprak oluşum ve özelliklerinde değişkenliklerin olduğu ve bunlar arasında önemli seviyede korelasyonların olduğu tespit edilmiştir.

Toprakların oluşumundan kaynaklanan ve yönetiminde etkili olabilecek özelliklerinin alt grup düzeyinde sınıflandırılmasının istatistiksel yaklaşımlarla ortaya konulabilirliği sürdürülebilir bir toprak yönetimi için oldukça önemlidir. Çalışma sonucunda, mikro ölçekte benzer iklim koşullarındaki toprakların sınıflaması ve uygun yönetim planlarının oluşturulması için istatistiksel ilişkilerin sisteme dâhil edilmesi sonuçların doğruluğunu arttıracağı öngörülmektedir.

\section{Kaynaklar}

Alaboz, P., Demir, S., Başayiğit, L., Işı1ldar, A.A., 2019. Isparta ili büyük toprak gruplarına göre tahıl yetiştirilen toprakların bazı özelliklerinin belirlenmesi. Tarla Bitkileri Merkez Araşstırma Enstitüsü Dergisi, 28(2): 67-79.

Alaboz, P., Demir, S., Dengiz, O., 2020. Farkl1 enterpolasyon yöntemleri kullanılarak toprakların nem sabitelerine ait konumsal dağılımların belirlenmesi, Isparta Atabey Ovası örneği. Tekirdă̆ Ziraat Fakültesi Dergisi, 17(3): 432-444.

Alaboz, P., Demir, S., Dengiz, O., 2021a. Assessment of various pedotransfer functions for the prediction of the dry bulk density of cultivated soils in a semiarid environment. Communications in Soil Science and Plant Analysis, 52(7): 724-742.

Alaboz, P., Dengiz, O., Demir, S., Şenol, H., 2021 b. Digital mapping of soil erodibility factors based on decision tree using geostatistical approaches in terrestrial ecosystem. CATENA, 207: 105634.

Anonim, 2021. Isparta İli Meteorolojik Verileri. Meteoroloji Genel Müdürlüğü, (http://www. mgm.gov.tr/veridegerlendirme/yillik-toplam-yagis verileri.aspx\#sfU), (Erişim tarihi: 08.04.2021).

Anonymous, 2004. National Soil Survey Characterization Data. Soil Survey Staff, Soil Survey Laboratory, National Soil Survey Center. USDA-NRCS, Lincoln, NE.

Anonymous, 2014. Keys to Soil Taxonomy (12th Ed.), USDA National Resources Conservation Services, Washington DC.

Anonymous, 2015. World Reference Base for Soil Resources. International Soil Classification System for Naming Soils and Creating Legends for Soil 
Maps. World Soil Resources Reports No. 106, FAO, Rome, Italy, pp. 181.

Azlan, A., Aweng, E.R., Ibrahim, C.O., Noorhaidah, A., 2012. Correlation between soil organic matter, total organic matter and water content with climate and depths of soil at different land use in Kelantan, Malaysia. Journal of Applied Sciences and Environmental Management, 16(4): 353-358.

Başayiğit, L., Şenol, H., Müjdeci, M., 2008. Isparta ili meyve yetiştirme potansiyeli yüksek alanların bazı toprak özelliklerinin coğrafi bilgi sistemleri ile haritalanmas1. Ziraat Fakültesi Dergisi, 3(2): 1-10.

Benesty, J., Chen, J., Huang, Y., Cohen, I., 2009. Pearson Correlation Coefficient. In Noise Reduction in Speech Processing, Vol: 2, Springer, Berlin, Heidelberg, pp. 1-4.

Bouyoucos, G.J., 1951. A recalibration of the hydrometer method for making mechanical analysis of soils. Agronomy Journal, 43(9): 434-438.

Burt, R., 2014. Soil Survey Field and Laboratory Methods Manual. United States Department of Agriculture, Natural Resources Conservation Service, National Soil Survey Center, Natural Resources Conservation Service, Kellog Soil Survey Laboratory.

Colombo, C., Palumbo, G., Sellitto, V.M., Di Iorio, E., Castrignanò, A., Stelluti, M., 2015. The effects of land use and landscape on soil nitrate availability in Southern Italy (Molise region). Geoderma, 239(240): $1-12$.

Conforti, M., Longobucco, T., Scarciglia, F., Niceforo, G., Matteucci, G., Buttafuoco, G., 2020. Interplay between soil formation and geomorphic processes along a soil catena in a Mediterranean mountain landscape: an integrated pedological and geophysical approach. Environmental Earth Sciences, 79(2): 116.

Corine, 2018. Corine Land Use Land Cover Map of Turkey. (https://corinecbs.tarimorman.gov.tr), (Erişim tarihi: 08.04.2021).

Çelik, P., Dengiz, O., 2018. Akselendi Ovası tarım topraklarının temel toprak özellikleri ve bitki besin elementi durumlarının belirlenmesi ve dağılım haritalarının olușturulması. Türkiye Tarımsal Araştırmalar Dergisi, 5(1): 9-18.

Das, A.K., Purkait, A., 2020. Boron dynamics in soil: classification, sources, factors, fractions, and kinetics. Communications in Soil Science and Plant Analysis, 51(22): 2778-2790.

Dedeoğlu, M., Özaytekin, H., Başayiğit, L., 2020. Orta Anadolu Bölgesi aridisol topraklarının özellikleri ve arazi değerlendirmesi. Anadolu Tarım Bilimleri Dergisi, 35(3): 419-429.

Dengiz, O., 2010. Morphology, physico-chemical properties and classification of soils on terraces of the Tigris River in the south-east Anatolia region of Turkey. Tarım Bilimleri Dergisi, 16(3): 205-2012.

Dengiz, O., Başkan, O., 2010. Characterization of soil profile development on different landscape in semiarid region of Turkey a case study; Ankara-Soğulca catchment. Anadolu Tartm Bilimleri Dergisi, 25(2): 106-112.
Dengiz, O., Usul, M., 2018. Multi-criteria approach with linear combination technique and analytical hierarchy process in land evaluation studies. Eurasian Journal of Soil Science, 7(1): 20-29.

Görmüş, M., Karaman, E., 1992. Facies changes and new stratigraphical paleontological data in the cretaceous tertiary boundary around Söbüdağ (Çünür-Isparta). Geosound, 21(1): 43-58.

Hanay, A., Şahin, Ü., Canbolat, M., Anapalı, Ö., 1996. Sabit seviveli permeametre yönteminde farkl1 potansivometrik vüklerin toprakların hidrolik iletkenliklerine etkisi. Atatürk Üniversitesi Ziraat Fakültesi Dergisi, 27(2): 272-283.

$\mathrm{Hu}$, C., Wright, A.L., Lian, G., 2019. Estimating the spatial distribution of soil properties using environmental variables at a catchment scale in the loess hilly area, China. International Journal of Environmental Research and Public Health, 16(3): 491.

Jackson, M.L., 1958. Soil Chemical Analysis. PrenticeHall, Inc. Englewood Cliffs, New Jersey, USA, pp, 498: $183-204$

Jenny, H., 1946. Arrangement of soil series and types according to functions of soil-forming factors. Soil Science, 61(5): 375-392.

Kacar, B., 2009. Toprak Analizleri. Nobel Yayın No: 1387, Fen Bilimleri: 90, Nobel Bilim ve Araştırma Merkezi Yayın No: 44, Genişletilmiş 2. Basım, Ankara, 467s.

Karaca, S., Dengiz, O., Demirağ Turan, İ., Özkan, B., Dedeoğlu, M., Gülser, F., Sargin, B., Demirkaya, S., Ay, A., 2021. An assessment of pasture soils quality based on multi-indicator weighting approaches in semi-arid ecosystem. Ecological Indicators, 121: 107001.

Karacan, T.N., Özaytekin, H.H., Dedeoğlu, M., 2016 Orta Anadolu'da yarı kurak iklim şartları altında ana materyale bağlı olarak bazı verimlilik parametrelerinin değerlendirilmesi. Çukurova Tarım Glda Bilimleri Dergisi, 31(3): 61-71.

Karahan, G., Erşahin, S., Öztürk, H.S., 2014. Toprak koşullarına bağlı olarak tarla kapasitesi dinamiği. Gaziosmanpaşa Üniversitesi Ziraat Fakültesi Dergisi, 30(1): 1-9.

Karaman, M.E., Meriç, E., Tansel, İ., 1988. Çünür (Isparta) dolaylarında Kretase-Tersiyer geçişi. Akdeniz Üniversitesi Isparta Mühendislik Fakültesi Dergisi, 4: 80-100.

Kars, N., Eekberli, İ., 2019. Çarşamba Ovası'nda işlenen tarım alanlarının bazı fiziksel ve kimyasal toprak özelliklerinin incelenmesi. Anadolu Tarım Bilimleri Dergisi, 34(2): 210-219.

Owliaie, H., Ghiri, M.N., Shakeri, S., 2018. Soillandscape relationship as indicated by pedogenesis data on selected soils from Southwestern, Iran. Eurasian Journal of Soil Science, 7(2): 167-180.

Özyazıc1, M.A., Dengiz, O., Aydoğan, M., Bayraklı, B., Kesim, E., Urla, Ö., Y1ldız, H., Ünal, E., 2015. Orta ve Doğu Karadeniz Bölgesi tarım topraklarının bazı makro ve mikro bitki besin maddesi konsantrasyonları ve ters mesafe ağırlık yöntemi 
(IDW) ile haritalanması. Artvin Çoruh Üniversitesi Orman Fakültesi Dergisi, 16(2): 187-202.

Özyazıcı, M.A., Dengiz, O., Aydoğan, M., Bayraklı, B., Kesim, E., Urla, Ö., Yıldı, H., Ünal, E., 2016. Orta ve Doğu Karadeniz Bölgesi tarım topraklarının temel verimlilik düzeyleri ve alansal dağılımları. Anadolu Tarım Bilimleri Dergisi, 31(1): 136-148.

Pearson, K., 1900. X. On the criterion that a given system of deviations from the probable in the case of a correlated system of variables is such that it can be reasonably supposed to have arisen from random sampling. The London, Edinburgh, and Dublin Philosophical Magazine and Journal of Science, 50(302): 157-175.

Peech, M., Alexander, L.T., Dean, L.A., Fielding Reed, J., 1947. Methods of Soil Analysis for Soil-Fertility İnvestigations. Washington, D.C., U.S. Department of Agriculture, No. 757.

Polat, K., Oğuz, İ., Koçyiğit, R., 2021. Yarı kurak iklim koşullarında eğimin farklı bölümlerinin aşınıma duyarlılıklarının karşılaştııılması. Uluslararası Tarım ve Yaban Hayatı Bilimleri Dergisi, 7(1): 115125.

Rasool, T., Dar, A.Q., Wani, M.A., 2020. Quantification of spatial variability of soil physical properties in a lesser Himalayan sub-basin of India. Eurasian Soil Science, 53(3): 362-376.

Sağlam, M., 2013. Çok değişkenli istatistiksel yöntemler ile toprak özelliklerinin gruplandırılması. Toprak $\mathrm{Su}$ Dergisi, 2(1): 7-14.

Sağlam, M., Dengiz, O., 2015. Similarity analysis of soils formed on limestone/marl-alluvial parent material and different topography using some physical and chemical properties via cluster and multidimensional scaling methods. Environmental Monitoring and Assessment, 187(3): 1-12.

Sorokin, A., Owens, P., Láng, V., Jiang, Z.D., Michéli, E., Krasilnikov, P., 2021. "Black soils" in the Russian soil classification system, the US Soil Taxonomy and the WRB: Quantitative correlation and implications for pedodiversity assessment. CATENA, 196: 104824.

Şenol, H., Alaboz, P., Demir, S., Dengiz, O., 2020b. Computational intelligence applied to soil quality index using GIS and geostatistical approaches in semiarid ecosystem. Arabian Journal of Geosciences, 13(23): 1-20.

Şenol, H., Alaboz, P., Dengiz, O., 2020a. Evaluation of the physico-chemical and nutrient elements status of soils formed on different parent materials using interpolation method. Anadolu Tarm Bilimleri Dergisi, 35(3): 505-516.

Şenol, H., Özaytekin, H.H., Akgül, M., Alaboz, P., 2014. Effect of aspect on weathering rates and clay mineralogy of soils developed on andesite/trachyandesite parent materials under semiarid conditions. Tarım Bilimleri Dergisi, 20(3): 288301.

Tukey, J.W., 1977. Exploratory Data Analysis. AddisonWesley Publishing Company, Vol. 2, pp. 131-160.

Tunçay, T., Dengiz, O., Bayramin, I., Kilic, S., Baskan, O., 2019. Chemical weathering indices applied to soils developed on old lake sediments in a semi-arid region of Turkey. Eurasian Journal of Soil Science, 8(1): 60-72.

Vasu, D., Singh, S.K., Sahu, N., Tiwary, P., Chandran, P., Duraisami, V.P., Ramamurthy, V., Lalitha, M., Kalaiselvi, B., 2017a. Assessment of spatial variability of soil properties using geospatial techniques for farm level nutrient management. Soil and Tillage Research, 169: 25-34.

Vasu, D., Singh, S.K., Tiwary, P., Chandran, P., Ray, S.K., Duraisami, V.P., 2017b. Pedogenic processes and soil-landform relationships for identification of yield-limiting soil properties. Soil Research, 55(3): 273-284.

Wilding, L.G., 1985. Soil spatial variability: its documentation, accomodation and implication to soil surveys. In: D.R. Nielsen and J. Bouma (Eds.), Soil Spatial Variability Proceedings of a Workshop of the ISSS and the SSA, Las Vegas PUDOC, Wageningen, 30 November-1 December 1984, pp. 166-187.

Wilson, S.G., Lambert, J.J., Nanzyo, M., Dahlgren, R.A., 2017. Soil genesis and mineralogy across a volcanic lithosequence. Geoderma, 285: 301-312.

Wolf, B., 1971. The determination of boron in soil extracts, plant materials, composts, manures, water and nutrient solutions. Communications in Soil Science and Plant Analysis, 2(5): 363-374.

Yalçınkaya, S., 1989. Isparta-Ağlasun (Burdur) dolaylarının jeolojisi. Doktora tezi, İstanbul Üniversitesi, Fen Bilimleri Enstitüsü, İstanbul.

Yıldız, A., Toker, V., 1991. Çünür köyü yöresindeki (Isparta kuzeyi) üst kretase-eosen yaşlı birimlerin plantik foraminiferler ile biyostratigrafik incelenmesi. Türkiye Jeoloji Bülteni, 34(2): 43-58. 